\title{
The anatomical distribution of single leprosy lesions in an African population, and its implications for the pathogenesis of leprosy
}

\author{
J M PONNIGHAUS, * P E M FINE, $\dagger$ \\ P J K GRUER, ${ }^{*} \&$ N MAINE $\dagger$ \\ *Lepra Evaluation Project, PO Box 46, Chilumba, Malaŵi; \\ $\dagger$ London School of Hygiene and Tropical Medicine, London \\ WCIE $7 H T, U K$
}

Accepted for publication 30 March 1990

\begin{abstract}
Summary Data on the anatomical sites of single leprosy lesions found in 635 newly diagnosed and biopsy-confirmed leprosy patients are presented. These patients were found during total population surveys carried out by the Lepra Evaluation Project, a prospective longitudinal study of the epidemiology of leprosy in Karonga District, Northern Malawi. There was a striking excess of single lesions on the face and the back of the arms, compared to the distribution of skin surface area, and a deficit on the legs, regardless of age. There is some evidence for a sex difference in lesion distribution among adults, with facial and arm lesions being relatively more common in females and back lesions being more common in males. The excess of lesions on the face compared to the lower limbs is similar to data from Uganda, but very unlike data from Burma and elsewhere in Asia. Overall, the distribution of lesions does not suggest a pattern reflecting entry of Mycobacterium leprae, nor does it suggest an association with anatomical distribution of the nervous or vascular system. It is argued that the distribution reflects the influence of some 'local' environmental or behavioural factors.
\end{abstract}

\section{Introduction}

Continued uncertainty over the natural history of leprosy has encouraged several workers to investigate the possible relevance of the anatomical distribution of leprosy lesions for the transmission of Mycobacterium leprae or the pathogenesis of subsequent clinical disease. The predilection of $M$. leprae for the skin was once taken as evidence for skin-toskin transmission of the infection. ${ }^{1}$ This view has been challenged in recent decades by investigations demonstrating that skin is an unlikely portal of exit for bacilli compared to the respiratory tract. ${ }^{2}$

The most thorough studies of the distribution of leprosy skin lesions and their implications were carried out by Doull et al. ${ }^{3}$ in the context of population studies in the Philippines. They found an excess of lesions on the extremities, and commented cautiously that, although the lesion distribution might be an indicator of skin entry, 'It 
should be borne in mind that such a distribution of lesions could be satisfactorily explained by assuming a portal of entry other than the skin, with a tendency to localization of the infection wherever the resistance of tissues is lowered by inflammation or injury'. Similar findings and opinions were later published by Guinto \& Rodrigues, ${ }^{4}$ also based on studies in the Philippines. Newell reviewed data published up to 1965 on lesion distributions in different age and sex groups, and concluded that there was no evidence favouring the skin, rather than the respiratory tract, as the major portal of entry of $M$. leprae. ${ }^{5}$ More recently, Machin ${ }^{6}$ has argued that in children the distribution of single leprosy lesions is essentially random, suggesting a systemic distribution of the infection.

A major problem in evaluating lesion distribution data is the fact that observed distributions of lesions are affected strongly by the methods of skin examination. Skin examinations may be incomplete, and social taboos or staff habits are such that certain parts of the body are liable to be examined less frequently and less thoroughly than others. This is particularly true for female suspects or patients in Asia. Published data from South India indicating lesions to be more common on legs and buttocks of males than of females are consistent with such a bias. ${ }^{2}$ Such distributions are impossible to interpret without detailed information on the methods and relative thoroughness of the examinations of the two sexes.

In this paper we present and analyse a unique data set derived from complete examination of more than $97 \%$ of people living in a leprosy endemic area in Northern Malawi. The work was carried out as a part of the LEPRA Evaluation Project.

\section{Methods}

The LEPRA Evaluation Project (LEP) is a prospective longitudinal study of the epidemiology of leprosy in Karonga District (population approximately 150,000 in 1990), Northern Malawi. ${ }^{7}$ The first total population survey was carried out between 1980 and 1984, and the second between 1985 and 1989. Individuals are examined at their homes by trained paramedical workers (leprosy control assistants, LCAs) who complete a 2-page 'General Examination Form' for every individual seen. In addition to entering any findings which might be signs of leprosy LCAs indicate whether they consider the examination to have been 'complete' or 'incomplete'. For all incomplete examinations the part of the body which was inadequately examined is indicated on the form. 'Incomplete' usually means that the buttocks were not seen. Only the lower abdomen (below the umbilicus) is omitted from the routine examination of adults, and is not generally examined unless an individual self-presents with a lesion on that part of the body. Regular supervision by medical officers (JMP, PJKG) and a senior LCA ensure adherence to protocol. Ninety-seven per cent of examinations have been recorded as complete.

All individuals suspected of having clinical leprosy (and who have no history of previous antileprosy treatment) are referred to an LEP Medical Officer (JMP or PJKG) for review examination. All lesions are then drawn onto an outline of the human body superimposed upon a grid. ${ }^{8}$ During these review examinations a numerical grade indicating the clinical certainty of the diagnosis of leprosy is given by the medical officer, ${ }^{9}$ and one or more $4 \mathrm{~mm}$ punch biopsy specimens are taken for histopathological examination. ${ }^{10}$ The clinical certainty grade, slit-skin smear results and histopathology 
results are coded, entered onto computer, and then combined in an algorithm to provide an overall measure of diagnostic certainty. ${ }^{9}$ For the purpose of this analysis only patients with a high overall certainty of diagnosis, ( $\mathrm{N}$ and $\mathrm{M}$ cases, see ref. 9) were considered.

The clinical records of all new (previously untreated) leprosy cases ascertained between 1980 and 1987 (inclusive) were reviewed. The large majority of these cases had been found by active case detection during the first total population survey (1980-84) or the first half of the second survey (1985-87). Patients with only a single lesion (including up to 2 small satellites), when first diagnosed, were selected for this study. Grid location codes for the initial lesion were entered into a computer, and combined with other demographic and clinical information for analysis. Anatomical distributions of lesions were compared with standard statistics on the distribution of skin surface area. ${ }^{11}$

Because adult females were slightly less likely than adult males to be completely examined in the general survey, ${ }^{7}$ we have excluded patients with single buttock lesions ( 6 females and 12 males) from the analysis comparing male and female adults.

\section{Results}

Table 1 shows the anatomical distribution of lesions by mode of detection. The difference between the self-reporting and actively found patients is not statistically significant and thus they are combined for all subsequent analyses. On the other hand it is of interest that only $9 \%$ of self-reporting patients had lesions on the back, whereas single back lesions were found on $22 \%$ of those ascertained by active case detection.

Table 2 shows the distribution of lesion sites by age for males and females together. There is no significant difference in the overall anatomical distribution of single leprosy lesions by age $\left(\chi^{2}=11.98, p=0 \cdot 75\right)$. For all age groups there is a preponderance of single lesions on the face, back and on the back of the arms. Together these sites account for $74 \%$ of single lesions found in new patients in Karonga District.

Figures 1 and 2 compare the distributions of lesions with the distribution of surface area of the skin in each anatomical location. ${ }^{11}$ The differences between lesion and skin distribution are striking, and are strongly statistically significant $(p<0.001$ by comparing

Table 1. Numbers (and percentages) of newly diagnosed leprosy patients with single lesions in Karonga District, Northern Malawii, by mode of ascertainment and site of lesion

\begin{tabular}{|c|c|c|c|c|c|c|c|c|c|c|}
\hline \multirow[b]{2}{*}{$\begin{array}{l}\text { Mode of } \\
\text { detection }\end{array}$} & \multicolumn{10}{|c|}{ Anatomical site } \\
\hline & Face & $\begin{array}{l}\text { Chest } \\
\text { (ant. } \\
\text { trunk) }\end{array}$ & $\begin{array}{l}\text { Back } \\
\text { (post. } \\
\text { trunk) }\end{array}$ & Buttocks & $\begin{array}{c}\text { Arms } \\
\text { (front) }\end{array}$ & $\begin{array}{c}\text { Arms } \\
\text { (back) }\end{array}$ & Hands & $\begin{array}{l}\text { Legs } \\
\text { (front) }\end{array}$ & $\begin{array}{l}\text { Legs } \\
\text { (back) }\end{array}$ & Total \\
\hline $\begin{array}{l}\text { Actively } \\
\text { detected }\end{array}$ & $\begin{array}{l}152 \\
(27 \%)\end{array}$ & $\begin{array}{l}18 \\
(3 \%)\end{array}$ & $\begin{array}{l}125 \\
(22 \%)\end{array}$ & $\begin{array}{l}25 \\
(4 \%)\end{array}$ & $\begin{array}{l}43 \\
(8 \%)\end{array}$ & $\begin{array}{l}133 \\
(24 \%)\end{array}$ & $\begin{array}{c}5 \\
(0 \cdot 1 \%)\end{array}$ & $\begin{array}{l}34 \\
(6 \%)\end{array}$ & $\begin{array}{l}22 \\
(4 \%)\end{array}$ & 557 \\
\hline $\begin{array}{l}\text { Self- } \\
\text { reporting }\end{array}$ & $\begin{array}{l}26 \\
(33 \%)\end{array}$ & $\begin{array}{l}0 \\
(0 \%)\end{array}$ & $\begin{array}{l}7 \\
(9 \%)\end{array}$ & $\begin{array}{l}1 \\
(1 \%)\end{array}$ & $\begin{array}{c}7 \\
(9 \%)\end{array}$ & $\begin{array}{l}27 \\
(35 \%)\end{array}$ & $\begin{array}{l}1 \\
(1 \%)\end{array}$ & $\begin{array}{l}5 \\
(6 \%)\end{array}$ & $\begin{array}{l}4 \\
(5 \%)\end{array}$ & 78 \\
\hline Total & $\begin{array}{l}178 \\
(28 \%)\end{array}$ & $\begin{array}{l}18 \\
(3 \%)\end{array}$ & $\begin{array}{l}132 \\
(21 \%)\end{array}$ & $\begin{array}{l}26 \\
(4 \%)\end{array}$ & $\begin{array}{l}50 \\
(8 \%)\end{array}$ & $\begin{array}{l}160 \\
(25 \%)\end{array}$ & $\begin{array}{l}6 \\
(1 \%)\end{array}$ & $\begin{array}{l}39 \\
(6 \%)\end{array}$ & $\begin{array}{l}26 \\
(4 \%)\end{array}$ & 635 \\
\hline
\end{tabular}


Table 2. The anatomical distribution of single leprosy lesions by age for males and females among newly diagnosed leprosy patients in Karonga District, Northern Malaŵi

\begin{tabular}{|c|c|c|c|c|c|c|c|c|c|c|}
\hline \multirow[b]{2}{*}{$\begin{array}{l}\text { Age } \\
\text { (years) }\end{array}$} & \multicolumn{10}{|c|}{ Anatomical site } \\
\hline & Face & $\begin{array}{l}\text { Chest } \\
\text { (ant. } \\
\text { trunk) }\end{array}$ & $\begin{array}{c}\text { Back } \\
\text { (post. } \\
\text { trunk) }\end{array}$ & Buttocks & $\begin{array}{l}\text { Arms } \\
\text { (front) }\end{array}$ & $\begin{array}{l}\text { Arms } \\
\text { (back) }\end{array}$ & Hands & $\begin{array}{l}\text { Legs } \\
\text { (f ront) }\end{array}$ & $\begin{array}{c}\text { Back } \\
\text { (front) }\end{array}$ & Total \\
\hline $0-10$ & $\begin{array}{l}16 \\
(35 \%)\end{array}$ & $\begin{array}{l}3 \\
(7 \%)\end{array}$ & $\begin{array}{c}8 \\
(17 \%)\end{array}$ & $\begin{array}{l}2 \\
(4 \%)\end{array}$ & $\begin{array}{l}3 \\
(7 \%)\end{array}$ & $\begin{array}{c}9 \\
(20 \%)\end{array}$ & $\begin{array}{c}0 \\
(0 \%)\end{array}$ & $\begin{array}{c}1 \\
(2 \%)\end{array}$ & $\begin{array}{c}4 \\
(9 \%)\end{array}$ & 46 \\
\hline $11-20$ & $\begin{array}{l}36 \\
(26 \%)\end{array}$ & $\begin{array}{l}4 \\
(3 \%)\end{array}$ & $\begin{array}{l}27 \\
(20 \%)\end{array}$ & $\begin{array}{c}6 \\
(4 \%)\end{array}$ & $\begin{array}{l}10 \\
(7 \%)\end{array}$ & $\begin{array}{l}33 \\
(24 \%)\end{array}$ & $\begin{array}{l}1 \\
(1 \%)\end{array}$ & $\begin{array}{l}11 \\
(8 \%)\end{array}$ & $\begin{array}{l}8 \\
(6 \%)\end{array}$ & 136 \\
\hline$>20$ & $\begin{array}{l}126 \\
(28 \%)\end{array}$ & $\begin{array}{l}11 \\
(2 \%)\end{array}$ & $\begin{array}{l}97 \\
(21 \%)\end{array}$ & $\begin{array}{l}18 \\
(4 \%)\end{array}$ & $\begin{array}{l}37 \\
(8 \%)\end{array}$ & $\begin{array}{l}118 \\
(26 \%)\end{array}$ & $\begin{array}{l}5 \\
(1 \%)\end{array}$ & $\begin{array}{l}27 \\
(6 \%)\end{array}$ & $\begin{array}{l}14 \\
(3 \%)\end{array}$ & 453 \\
\hline Total & $\begin{array}{l}178 \\
(28 \%)\end{array}$ & $\begin{array}{l}18 \\
(3 \%)\end{array}$ & $\begin{array}{l}132 \\
(21 \%)\end{array}$ & $\begin{array}{l}26 \\
(4 \%)\end{array}$ & $\begin{array}{l}50 \\
(8 \%)\end{array}$ & $\begin{array}{l}160 \\
(25 \%)\end{array}$ & $\begin{array}{l}6 \\
(1 \%)\end{array}$ & $\begin{array}{l}39 \\
(6 \%)\end{array}$ & $\begin{array}{l}26 \\
(4 \%)\end{array}$ & 635 \\
\hline
\end{tabular}

likelihoods based on multinomial distributions) for both sexes. There is an excess of lesions relative to surface area on the face and the upper arms and to a lesser extent on the back of the trunk. The relative deficit of lesions is mostly on the legs. The deficit on the anterior trunk is an exaggeration in so far as the lower abdomen is not examined in adults.

Table 3 presents lesion distributions by sex, for individuals up to and older than 20 years at time of diagnosis. Buttock lesions are omitted from the adult analysis because of the slight difference between the sexes in completeness of examinations. ${ }^{7}$ Table 3 reveals

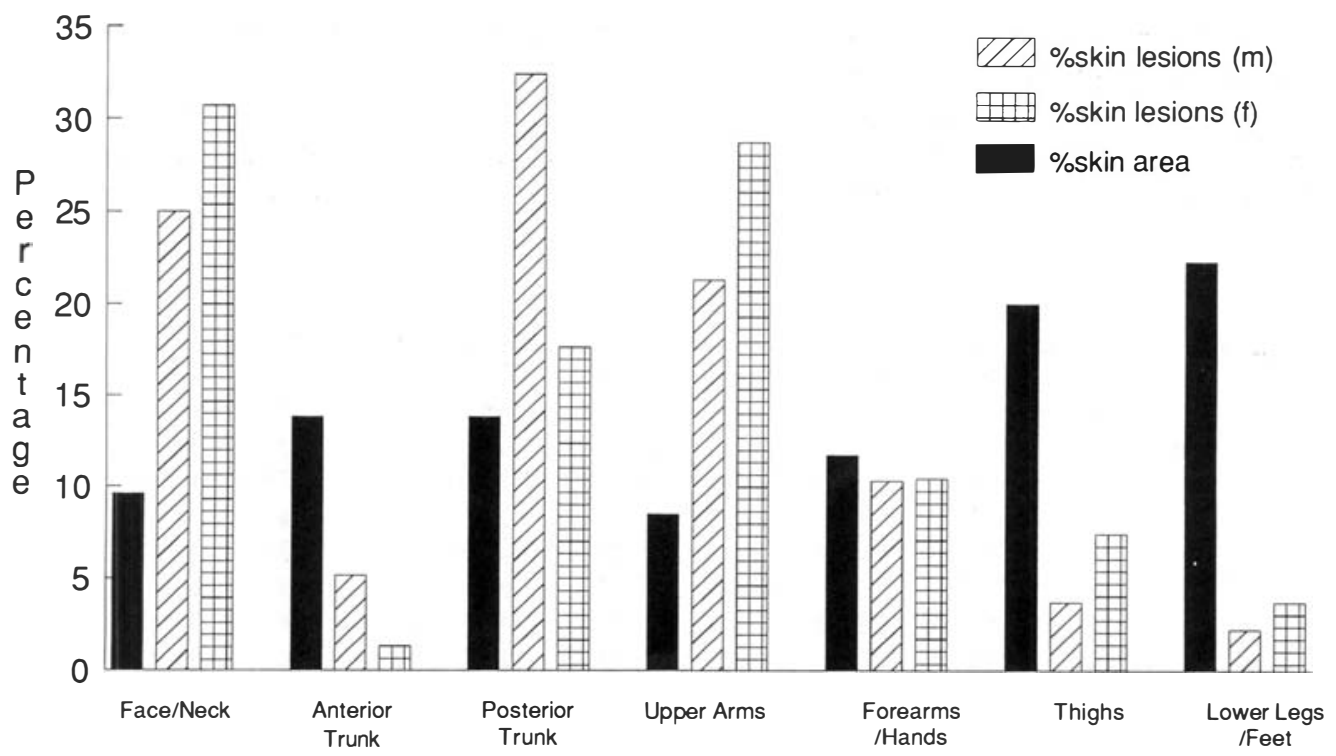

Figure 1. Anatomical distribution of single lesions among adult leprosy patients newly ascertained in Karonga District, Northern Malawi, by sex, compared with skin surface area distribution (buttocks and genital areas omitted). 


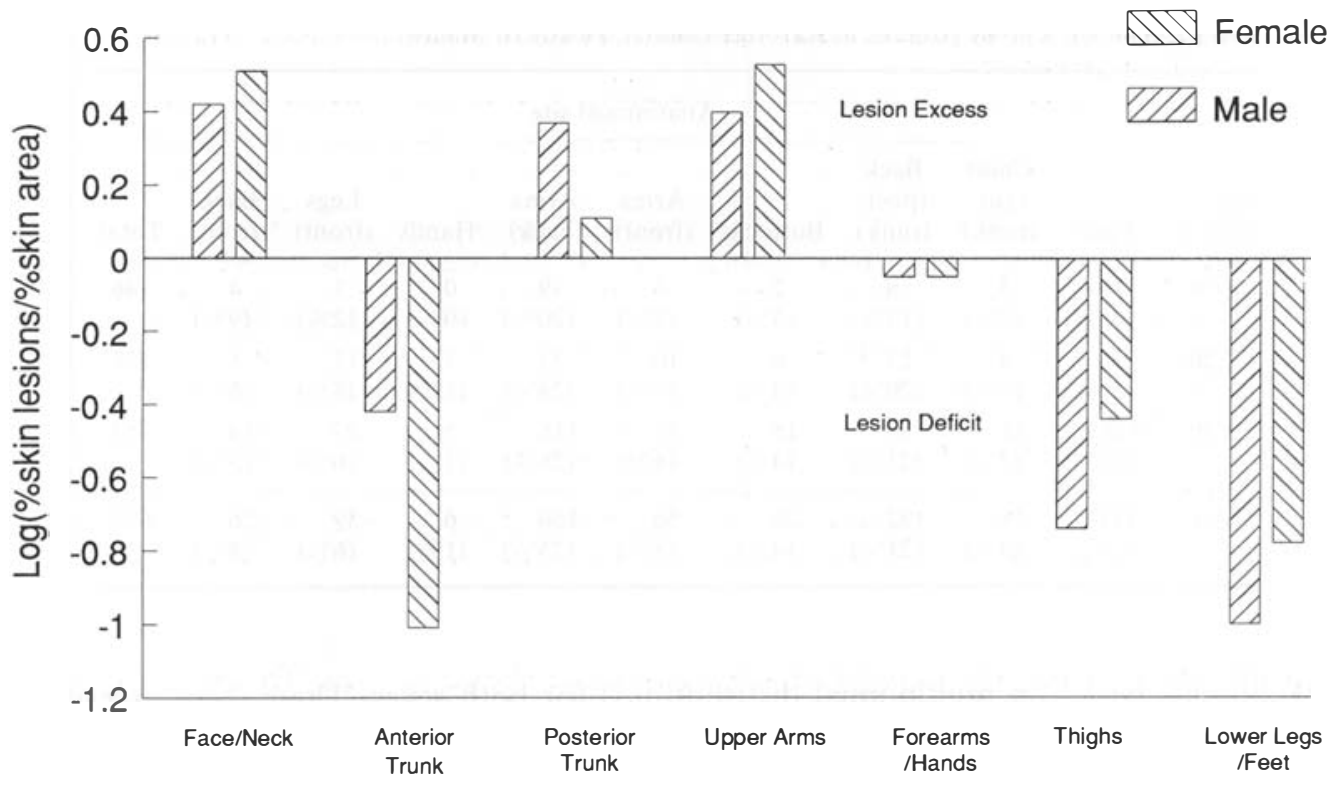

Figure 2. Relative excess and deficit of skin lesions in different anatomical sites, among adult leprosy patients newly ascertained in Karonga District, Northern Malawi, by sex. Vertical axis is the logarithm of the ratio of observed to expected relative frequencies, assuming that the lesions were randomly distributed on the body. Primary data identical to those presented in Figure 1.

Table 3. Distribution of new leprosy lesions by anatomical site, sex and age (up to and older than 20 years). Data from Karonga District, Northern Malawii. Buttock lesions of lesions of adults in square brackets

\begin{tabular}{|c|c|c|c|c|c|c|c|c|c|c|c|}
\hline \multirow[b]{2}{*}{$\begin{array}{l}\text { Age } \\
\text { (years) }\end{array}$} & \multicolumn{11}{|c|}{ Anatomical site } \\
\hline & Sex & Face & $\begin{array}{l}\text { Chest } \\
\text { (ant. } \\
\text { trunk) }\end{array}$ & $\begin{array}{l}\text { Back } \\
\text { (post. } \\
\text { trunk) }\end{array}$ & Buttocks & $\begin{array}{c}\text { Arms } \\
\text { (front) }\end{array}$ & $\begin{array}{c}\text { Arms } \\
\text { (back) }\end{array}$ & Hands & $\begin{array}{l}\text { Legs } \\
\text { (front) }\end{array}$ & $\begin{array}{l}\text { Legs } \\
\text { (back) }\end{array}$ & Total \\
\hline \multirow{4}{*}{$0-20$} & M & $\begin{array}{l}25 \\
(30 \%)\end{array}$ & $\begin{array}{l}5 \\
(6 \%)\end{array}$ & $\begin{array}{l}17 \\
(20 \%)\end{array}$ & $\begin{array}{c}4 \\
(5 \%)\end{array}$ & $\begin{array}{c}7 \\
(8 \%)\end{array}$ & $\begin{array}{l}15 \\
(18 \%)\end{array}$ & $\begin{array}{l}1 \\
(1 \%)\end{array}$ & $\begin{array}{l}6 \\
(7 \%)\end{array}$ & $\begin{array}{l}4 \\
(5 \%)\end{array}$ & 84 \\
\hline & $\mathrm{F}$ & $\begin{array}{l}27 \\
(28 \%)\end{array}$ & $\begin{array}{l}2 \\
(2 \%)\end{array}$ & $\begin{array}{l}18 \\
(18 \%)\end{array}$ & $\begin{array}{c}4 \\
(4 \%)\end{array}$ & $\begin{array}{l}6 \\
(6 \%)\end{array}$ & $\begin{array}{l}27 \\
(28 \%)\end{array}$ & $\begin{array}{c}0 \\
(0 \%)\end{array}$ & $\begin{array}{l}6 \\
(6 \%)\end{array}$ & $\begin{array}{l}8 \\
(8 \%)\end{array}$ & 98 \\
\hline & Both & $\begin{array}{c}52 \\
(29 \%)\end{array}$ & $\begin{array}{l}7 \\
(4 \%)\end{array}$ & $\begin{array}{l}35 \\
(19 \%)\end{array}$ & $\begin{array}{c}8 \\
(4 \%)\end{array}$ & $\begin{array}{l}13 \\
(7 \%)\end{array}$ & $\begin{array}{l}42 \\
(23 \%)\end{array}$ & $\begin{array}{l}1 \\
(1 \%)\end{array}$ & $\begin{array}{l}12 \\
(7 \%)\end{array}$ & $\begin{array}{l}12 \\
(7 \%)\end{array}$ & 182 \\
\hline & M & $\begin{array}{c}34 \\
(25 \%)\end{array}$ & $\begin{array}{l}7 \\
(5 \%)\end{array}$ & $\begin{array}{c}44 \\
(32 \%)\end{array}$ & {$[+12]^{*}$} & $\begin{array}{l}12 \\
(9 \%)\end{array}$ & $\begin{array}{l}29 \\
(21 \%)\end{array}$ & $\begin{array}{l}2 \\
(1 \%)\end{array}$ & $\begin{array}{c}4 \\
(3 \%)\end{array}$ & $\begin{array}{c}4 \\
(3 \%)\end{array}$ & 136 \\
\hline \multirow[t]{2}{*}{$>20$} & $\mathrm{~F}$ & $\begin{array}{c}92 \\
(31 \%)\end{array}$ & $\begin{array}{l}4 \\
(1 \%)\end{array}$ & $\begin{array}{l}53 \\
(18 \%)\end{array}$ & {$[+6]^{*}$} & $\begin{array}{l}25 \\
(8 \%)\end{array}$ & $\begin{array}{l}89 \\
(30 \%)\end{array}$ & $\begin{array}{l}3 \\
(1 \%)\end{array}$ & $\begin{array}{l}23 \\
(8 \%)\end{array}$ & $\begin{array}{l}10 \\
(3 \%)\end{array}$ & 299 \\
\hline & Both & $\begin{array}{l}126 \\
(30 \%)\end{array}$ & $\begin{array}{l}11 \\
(3 \%)\end{array}$ & $\begin{array}{l}97 \\
(2 \%)\end{array}$ & $\begin{array}{r}{[+18]} \\
{[4 \%]}\end{array}$ & $\begin{array}{l}37 \\
(9 \%)\end{array}$ & $\begin{array}{l}118 \\
(27 \%)\end{array}$ & $\begin{array}{l}5 \\
(1 \%)\end{array}$ & $\begin{array}{l}27 \\
(6 \%)\end{array}$ & $\begin{array}{l}14 \\
(3 \%)\end{array}$ & $\begin{array}{r}435 \\
{[+18]}\end{array}$ \\
\hline Total & & 178 & 18 & 132 & 26 & 50 & 160 & 6 & 39 & 26 & 635 \\
\hline
\end{tabular}

* Buttock lesions of adults not included in percentage calculations. 
Table 4. The anatomical distribution of single leprosy lesions in children and young individuals in Malaŵi, Uganda and Burma. Malawi data from this study. Uganda ${ }^{14}$ and Burma ${ }^{15}$ data from BCG trial populations

\begin{tabular}{|c|c|c|c|c|c|c|c|c|c|}
\hline \multirow[b]{2}{*}{ Population } & \multicolumn{9}{|c|}{ Anatomical site } \\
\hline & Face & Chest & Back & Buttocks & $\begin{array}{l}\text { Upper } \\
\text { Arms }\end{array}$ & $\begin{array}{c}\text { Forearms } \\
\text { + hands }\end{array}$ & Thighs & $\begin{array}{c}\text { Lower } \\
\text { legs } \\
+ \text { feet }\end{array}$ & Total \\
\hline $\begin{array}{l}\text { Karonga } \\
\text { District, } \\
\text { Malawi }\end{array}$ & $\begin{array}{l}52 \\
(29 \%)\end{array}$ & $\begin{array}{l}7 \\
(4 \%)\end{array}$ & $\begin{array}{l}35 \\
(19 \%)\end{array}$ & $\begin{array}{l}8 \\
(4 \%)\end{array}$ & $\begin{array}{l}32 \\
(18 \%)\end{array}$ & $\begin{array}{l}24 \\
(13 \%)\end{array}$ & $\begin{array}{l}15 \\
(8 \%)\end{array}$ & $\begin{array}{l}9 \\
(5 \%)\end{array}$ & 182 \\
\hline Uganda & $\begin{array}{l}79 \\
(44 \%)\end{array}$ & $\begin{array}{l}7 \\
(4 \%)\end{array}$ & $\begin{array}{l}17 \\
(9 \%)\end{array}$ & $\begin{array}{l}13 \\
(7 \%)\end{array}$ & $\begin{array}{l}32 \\
(18 \%)\end{array}$ & $\begin{array}{l}24 \\
(13 \%)\end{array}$ & $\begin{array}{l}15 \\
(8 \%)\end{array}$ & $\begin{array}{l}9 \\
(5 \%)\end{array}$ & 181 \\
\hline Burma & $\begin{array}{l}12 \\
(3 \%)\end{array}$ & $\begin{array}{l}13 \\
(3 \%)\end{array}$ & $\begin{array}{l}47 \\
(10 \%)\end{array}$ & $\begin{array}{l}86 \\
(18 \%)\end{array}$ & $\begin{array}{l}80 \\
(17 \%)\end{array}$ & $\begin{array}{l}75 \\
(16 \%)\end{array}$ & $\begin{array}{l}89 \\
(19 \%)\end{array}$ & $\begin{array}{l}65 \\
(14 \%)\end{array}$ & 469 \\
\hline
\end{tabular}

no difference between the sexes for individuals less than 20 years of age. On the other hand there appears to be a sex difference in lesion distribution among adults (heterogeneity $\chi^{2}=21 \cdot 51, p=0 \cdot 003$ ), with an excess of lesions on the trunk of males and on the face and back of arms of females.

Further analyses by occupation associated with different clothing requirements did not reveal any significant differences between the generally well-dressed teachers and office workers and the generally less well-dressed farmers and fishermen.

Table 4 and Figure 3 present data on the distribution of single leprosy lesions in

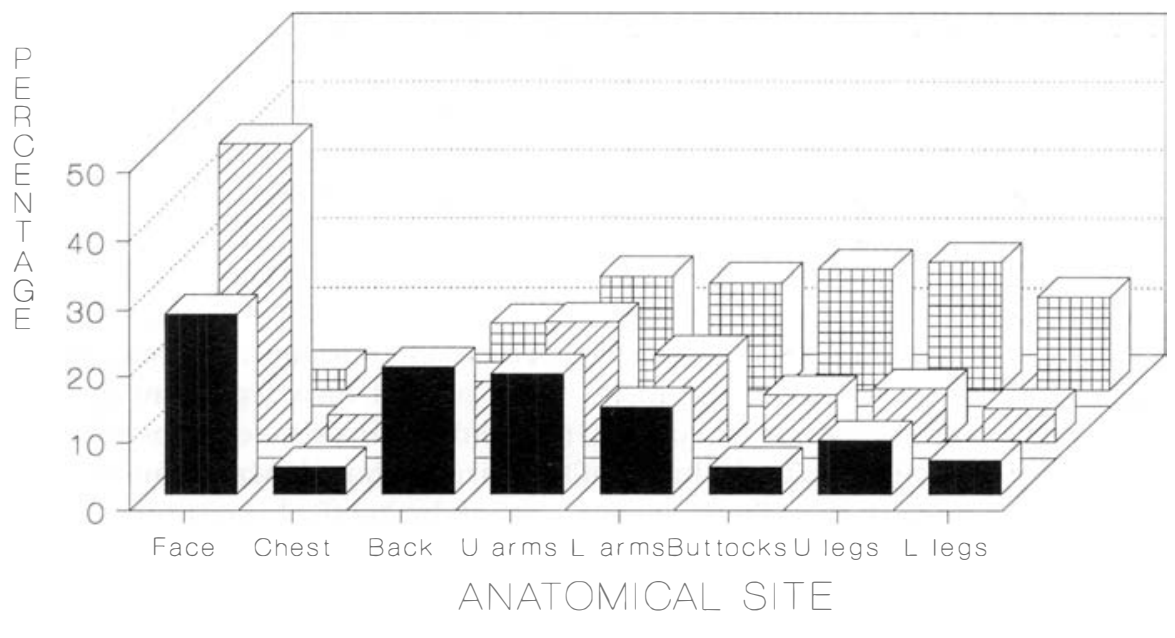

Malawi $(N=182) \quad$ ZIJganda $(N=181) \quad \#$ Burma $(N=469)$

Figure 3. Anatomical distribution of single lesions in young leprosy patients in Malawi (this study), Uganda ${ }^{12}$ and Burma. ${ }^{13}$ Data from Table 4. 
Malaŵi (this study), Uganda ${ }^{12}$ and Burma. ${ }^{13}$ All data refer to individuals less than 20 years of age and are unlikely to be influenced greatly by ascertainment bias. It appears that single lesions are far more common on the face than the buttocks or lower limbs of young African patients, and vice versa for the Burmese.

\section{Discussion}

The anatomical distribution of single leprosy lesions presented here is unlikely to have been distorted to an appreciable extent by incompleteness of examination. More than $96 \%$ of the general population, and all leprosy suspects, were examined completely, with the exception of the lower abdomen. Some parts of the body are more difficult to examine than others, in particular the feet and lower legs, which may be covered with dirt or dust. However, because the feet are closely inspected during the routine palpation of superficial peroneal nerves, it is unlikely that many lesions on the feet and lower legs escaped attention. Frequently LCAs ask people to wash their feet or lower legs if they believe that the examination may be hampered by dirt or dust. We therefore think that our main findings, a marked preponderance of lesions on the face in both sexes and all ages, an excess of lesions on the back of adult males and on the back of the arms of adult females, and a deficit of lesions on the legs in both sexes, at all ages, are genuine, and not artefacts due to incomplete examinations. It is of interest that single lesions on the back were more common among actively than passively detected patients, perhaps reflecting greater awareness of lesions which can be more easily observed. The fact that sex differences in lesion distribution are more apparent in adults than in children is reminiscent of the fact that sex differences in prevalence rates are also observed in adults but not in children. ${ }^{2,14}$

The distribution of single lesions found among leprosy patients in Karonga District is not consistent with the simple hypothesis that sites of single leprosy lesions reflect sites of entry of $M$. leprae through the skin via wounds or skin abrasions. The relative paucity of lesions on the legs speaks against that hypothesis. This deficit is in conspicuous contrast with the anatomical distribution of Buruli ulcer lesions, a mycobacterial disease believed to be transmitted through broken skin. Approximately $68 \%$ of Buruli ulcer lesions in adult males and $29 \%$ of the lesions in adult females have been reported to occur on the legs. ${ }^{15}$

On the other hand, it might be argued that the observed distribution of leprosy lesions in Karonga District does not contradict the hypothesis that $M$. leprae enter the skin via bites of flying insects, with subsequent local development of lesions. ${ }^{2,16}$ Men in Karonga District usually wear long trousers, which should protect their legs from insect bites. Women always cover the chest and back but frequently wear sleeveless tops which would allow flying insects easy access to the backs of their arms. Though Malawians in Karonga District usually sleep with their faces covered, except during the hottest time of the year (October and November), their faces are probably more exposed to flying-biting insects than are other parts of the body.

If the distribution of leprosy lesions does not reflect the sites of entry of $M$. leprae, then it must reflect either differential seeding or proliferation of $M$. leprae, or else differential pathological responses to infection, in different parts of the body. Such mechanisms might in turn reflect differential vascular or nervous supply to various parts of the body, or differential immune responses (perhaps based on density of Langerhans or other cell 
types), or else other factors such as body temperature. ${ }^{17}$ If the determining factors are physiological, we might expect the anatomical distribution of leprosy lesions to be similar in different populations. To test this hypothesis, we compared lesion distributions in three data sets which we believe to have been relatively little affected by selection or examination biases (Table 4, Figure 3). These data pertain to children (and thus avoid possible incompleteness of examination associated with taboos in adults) in this Malawian study and in the actively followed-up populations of the BCG trials in Uganda $^{12}$ and Burma. ${ }^{13}$ The two African data sets are roughly similar, with strong preailections for lesions on the face and a paucity of lesions on the buttocks, legs and feet. These distributions are in striking contrast to the Burmese data which show more than $50 \%$ of lesions on the buttocks and lower limbs, but only $3 \%$ of lesions on the face. Other published data sets from Indian and Philippine populations resemble those from Burma more than they do those from Malawi and Uganda, in that they show a higher predilection for lesions on the lower limbs than on the face. ${ }^{2,3,18,19}$

We believe these differences between African and Asian populations to be real, and not merely a reflection of biased data. The considerable difference between the anatomical distribution of single leprosy lesions in Burma and in Malawi makes it unlikely that 'universal' anatomical or physiological factors, such as skin surface temperature distribution, blood vessel distribution, peripheral nerve distribution or turnover rates of Schwann cell $\mathrm{s}^{20}$ determine the distribution of leprosy lesions, as such factors are unlikely to differ greatly between people in different parts of the world. The differences suggest rather that there are strictly 'local', presumably environmental or behavioural, factors which determine where single leprosy lesions arise. An important factor could be clothing and sleeping habits, if biting insects were involved in the transmission of $M$. leprae or if sun exposure were associated with response to infection. We could find no evidence in our data that clothing habits related to occupation were associated with the anatomical distribution of lesions, but such an indirect test of the hypothesis is obviously open to confounding by many extraneous occupation-related factors. The puzzle remains to be solved.

\section{Acknowledgments}

The Lepra Evaluation Project is funded primarily by the British Leprosy Relief Association (LEPRA) with assistance from the IMMLEP component of the WHO/TDR programme. The authors are grateful to these agencies and to the government of the Republic of Malawi for their interest and active support. Special thanks are due to the LEP field staff in Malawii, to Dr I Sutherland for providing unpublished data on the distribution of skin lesions in the Ugandan BCG trial population, and to Maria Simwaka Kauta for help in preparing the manuscript. Dr S Oxborrow made helpful comments on a previous draft.

\section{References}

1 Badger LF. In Leprosy in theory and practice. Cochrane \& Davey (eds), 1964, Ch. 6, pp 69-97.

2 Fine PEM. Leprosy: The epidemiology of a slow bacterium. Epidemiologic Reviews, 1982; 4: 161-88.

${ }^{3}$ Doull JA, Rodriguez JN, Guinto R, Plantilla F. Field study of leprosy in Cebu. Int J Lepr, 1936; 4: 141-70. 
4 Guinto RS, Rodriguez JN. A field study of leprosy in Talisay, Cebu, Philippines. Int J Lepr, 1941; 9: $149-66$.

5 Newell KW. An epidemiologist's view of leprosy. Bull Wld Hlth Org, 1966; 34: 827-57.

${ }^{6}$ Machin M. In Essays on leprosy. Ryan \& McDougall (eds). 1988, Ch. 1, pp 1-29.

7 Ponnighaus JM, Fine PEM, Bliss L, Sliney IJ, Bradley DJ, Rees RJW. The Lepra Evaluation Project (LEP) an epidemiological study of leprosy in Northern Malaŵi. I: Methods. Le pr Rev, 1987; 58: 359-75.

8 Boerrigter G. Grid system and body diagram for leprosy. Lepr Rev, 1983; 54: 115-18.

9 Ponnighaus JM, Fine PEM, Bliss L. Certainty levels in the diagnosis of leprosy. Int J Lepr, 1987; 55: 454-62.

10 McDougall CA, Ponnighaus JM, Fine PEM. Histopathological examination of skin biopsies from an epidemiological study of leprosy in Northern Malawii. Int J Lepr, 1987; 55: 88-98.

11 Lund CC, Browder NC. The estimation of areas of burns. Surg Gynec and Obst, 1944; 79: 352-8.

12 Sutherland I. Personal communication.

13 Bechelli LM, Gallego-Garbajosa P, Gyi MM, et al. Site of early skin lesions in children with leprosy. Bull WHO, 1973; 48: 107-11.

14 Ponnighaus JM, Fine PEM, Maine N, Bliss L, Kalambo M, Ponnighaus I. The Lepra Evaluation Project (LEP), an epidemiological study of leprosy in Northern Malawi. II. Prevalence rates. Lepr Rev, 1988; 59: $97-112$.

15 The Uganda Buruli Group. Epidemiology of mycobacterium ulcerans infection (Buruli ulcer) at Kinyara, Uganda. Trans Roy Soc Trop Med Hyg, 1971; 65: 763-75.

16 Kirchheimer WF. The role of anthropods in the transmission of leprosy. Int J Lepr, 1976; 44: 104-7.

17 Hastings RC, Brand PW, Mansfield RE, Ebner JD. Bacterial density in the skin in lepromatous leprosy as related to temperature. Lepr Rev, 1968; 39: 71-4.

18 Bedi BMS, Narayan E, Doss AG, Kirchheimer WF, Balasubrahmanyan M. Distribution of single lesions of tuberculoid leprosy. Le pr India, 1975; 57: 15-22.

19 Horton RJ, Povey S. The distribution of first lesions in leprosy. Lepr Rev, 1966; 37: 113-14.

20 Weddell AGM, Palmer E. The pathogenesis of leprosy. Lepr Rev, 1963; 34: 57-61. 